\title{
Performance Efficiency of Common Reed, Sand and Gravel for Greywater Treatment in a Constructed Wetland in Akure, Nigeria
}

\author{
Alao Femi", Alatise Micheal Olanrewaju, Olanrewaju Olawale \\ Department of Agricultural and Environmental Engineering, Federal University of Technology, Akure, Nigeria \\ Email address: \\ femmylaoo@gmail.com (A. Femi),femmylao@yahoo.com (A. Femi) \\ ${ }^{*}$ Corresponding author
}

\section{To cite this article:}

Alao Femi, Alatise Micheal Olanrewaju, Olanrewaju Olawale. Performance Efficiency of Common Reed, Sand and Gravel for Greywater Treatment in a Constructed Wetland in Akure, Nigeria. Journal of Civil, Construction and Environmental Engineering.

Vol. 6, No. 5, 2021, pp. 144-148. doi: 10.11648/j.jccee.20210605.13

Received: March 28, 2021; Accepted: May 10, 2021; Published: October 30, 2021

\begin{abstract}
The release of greywater lacking any treatments into drainage channels, land surfaces and normal water bodies will lead to environmental deprivation and health risks. In this study, common reed combined with natural materials of sand and gravel was used in a system of constructed wetland for the treatment of greywater in Akure, Nigeria. Raw greywater (RGW) was collected from Jadesola Hostel, Federal University of Technology, Akure, and pretreated using a combination of gravel with fine sand, arranged accordingly. The filtered water was subsequently released to a plastic constructed wetland (CW) consisting of similar combination of layers of gravel and sand with common reed planted on it to achieve complete treatment. The RGW, filtered greywater (FGW) and treated greywater (TGW) were analyzed for biochemical oxygen demand (BOD), chemical oxygen demand (COD), total suspended solid (TSS), total nitrogen (TN) and fecal coliforms (FC). Results showed reductions in BOD, COD, TSS, TN and FC by $80.20 \%, 78.35 \%, 56.07 \%, 45.93 \%$ and $74.71 \%$, respectively, for FGW and by $90.92 \%, 91.46 \%, 93.46 \%, 53.66 \%$ and $82.10 \%$, respectively, for TGW. Therefore, it was concluded that the combination of common reed, sand and gravels in constructed wetland offers an effective means of accomplishing physical and biological treatment of greywater, especially for reuse in irrigation. Hence, it was recommended that acceptance of the combined system will help farmers in ensuring sufficient treatment of greywater and satisfies the standard requirements for wastewater reuse and application in both field crop irrigation and other outdoor needs.
\end{abstract}

Keywords: Common Reed, Constructed Wetland, Fecal Coliforms, Gravel, Greywater, Sand

\section{Introduction}

Environmental pollution is a universal worry because of its harmful effects on public health and the environment. The reckless disposal of raw wastewater into surface waters, soil and groundwater results in contamination of water resources and environmental damage such as eutrophication. Meanwhile, the majority of the wastewater generated in many homes across the globe and particularly in Nigeria, is greywater. Greywater (GW) refers to wastewater from kitchen, bath and laundry excluding wastewater from toilets [35]. Generally, GW constitutes between $50 \%$ and $70 \%$ of all the wastewater disposed by every household [10, 11]. Currently, the world faces the challenges of insufficient freshwater supply such that reuse of GW for both indoor and outdoor purposes, including agricultural irrigation is now being suggested $[25,5]$. However, GW reuse also constitutes great risks to health, land and the environment and such risks become more serious if no treatment is considered before its reuse. Thus, there is the need for adequate treatment of greywater for its safe reuse.

In a well-structured urban wastewater collection and treatment system, greywater is usually channeled to a centrally placed urban treatment plant for its treatment. Nevertheless, source treatment of greywater has been described as the most efficient environmental protection, because it helps to avoid the generation of mixed waste streams and harmful emissions [13]. Accordingly, many 
biological and physicochemical techniques have been suggested to accomplish font treatment of greywater [5, 24]. Amongst the various biological methods of greywater treatment, the use of constructed wetlands (CWs) has become famous globally [31]. CWs are engineered systems aimed to employ natural practices for water quality developments. They play a remarkable part in the elimination of pollutants in wastewater treatment. They accomplish this role by eliminating pollutants in wastewaters through a mixture of physical (filtration, sedimentation), biological (microbial processes, plant uptake) and chemical (precipitation, adsorption) mechanisms.

The selection of substrates in a CW is determined in terms of the hydraulic permeability and the capacity of absorbing pollutants. Generally, the criteria for selecting substrates include low cost, close by readiness, high pollutant removal efficiency, good support for plant growth and microbial adhesion, non-toxic to microorganisms, sturdiness under washing, consistent hydraulic conductivity, recovery and disposal of spent substrate, among others [23, 33]. Several studies have been conducted on wetland substrata selection especially for sustainable phosphorus removal from wastewater $[2,28,8]$. In most of the studies, natural material, artificial media and industrial by-product including gravel, sand, clay, calcite, marble, slag, fly ash, activated carbon, amongst others, were the frequently used substrates $[2,28$, 36]. However, the studies further suggested substrates such as sand, gravel, and rock as poor candidates for long-term phosphorus storage, but in contrast, artificial and industrial products with high hydraulic conductivity and phosphorus sorption capacity could be alternative substrates in CWs. Other studies also recommended the use of substrates such as alum sludge, peat, maerl, compost and rice husk to attain optimal removal of nitrogen and organics [4, 28]. Moreover, a mixture of substrates (sand and dolomite) was applied in CWs in removal of phosphates [26], and mixed (substrate gravel, vermiculite, ceramsite and calcium silicate hydrate) was also used in CWs for treating surface water with low nutrients concentration [20]. These mixed substrates not only have reactive surfaces for microbial attachment, but also provide a high hydraulic conductivity to avoid shortcircuiting in CWs.

In $\mathrm{CWs}$, vegetation plays a partial role during treatment process, because it helps in providing oxygen to the microorganisms in the rhizosphere, lessen the quantity of nutrients in the system by uptake and perhaps provide more surface area in the rhizosphere for the microorganisms [7]. In this regard, the use of common reed is highly favoured. Common reed (Phragmites australis) is one of the most widely distributed wetland plant worldwide. It is a highly productive grass (Poaceae) with an above-ground net primary production ranging from, less than 3 ton/ha/year to as much as $30 \mathrm{ton} / \mathrm{ha} /$ year [3]. The plant can be found all over the world except in Antarctica, but its core distribution area is Europe, the Middle East and America [15]. It is characteristic of wet sites, most often with water level ranging from slightly below the soil surface to one metre above ground level $[7,1]$, and grows mostly at the shores of lakes and gulfs, along riverbanks and on nutrient-rich peatlands.

Despite the widely celebrated effectiveness of common reed in greywater treatment, its combined use with sand and gravel in a $\mathrm{CW}$ has the potential to ensure greater treatment efficiency apart from the prevention of pipe clogging, because both the gravel and sand serve as filter materials. Moreover, the long roots of the common reed, up to $2 \mathrm{~m}$, can burrow through the whole filter material, thus improving the functioning of the filter and preventing clogging. Hence, proper and effective aeration of the filter is reached with the help of the common reed (Phragmites australis) that has demonstrated good performance in practice [21]. However, despite the widespread use of common reed and both sand and gravel as substrates in $\mathrm{CW}$ technology for greywater treatment around the world, to the best of our knowledge, its performance with respect to studies in Nigeria is rare in the literature. Thus, the aim of this study was to investigate the efficiency of common reed, sand and gravels for GW treatment in a CW in Akure, Nigeria.

\section{Materials and Method}

The study was carried out at the back of Jadesola Akande Female Hostel, Obanla Campus, of the Federal University of Technology, Akure (FUTA), Nigeria. Akure is located within the sub-humid tropical climate of Nigeria on Latitude $7^{\circ} 16^{\prime} \mathrm{N}$ and Longitude $5^{\circ} 15^{\prime} \mathrm{E}$, with two distinct seasons. In Akure there is yearly dry season from November to March and a rainy season from April to October. Average annual rainfall ranges between $1405 \mathrm{~mm}$ and $2400 \mathrm{~mm}$ of which raining season accounts for $90 \%$ and the month of April marks the beginning of rainfall. Influent greywater was sourced from the aforementioned hostel which provides accommodation for about 200 female students. Water from baths, showers, kitchen and bathrooms were drained through pipes of diameter $128 \mathrm{~mm}$ to an underground $500 \mathrm{~L}$ water reservoir that served as a holding/sedimentation tank for greywater. During the experiment, pretreatment took place in a $500 \mathrm{~L}$ cylindrical container, where food particles and other suspended solids (hair and lint) were filtered through a media of gravels (diameters $32 \mathrm{~mm}, 24 \mathrm{~mm}$, and $16 \mathrm{~mm}$ ) and a final layer of fine sand (diameter $0.2 \mathrm{~mm}$ ) arranged, accordingly. Filtered greywater (FGW) was then released from the pretreatment container through a pipe of diameter $32 \mathrm{~mm}$ into the $\mathrm{CW}$. The $\mathrm{CW}$ is a plastic container of surface diameter $1.5 \mathrm{~m}$ and depth $0.6 \mathrm{~m}$. It also consisted of filters as in the sedimentation tank with common reed planted on it. The importance of the common reed is to treat the greywater biologically. The retention time of the FGW in the CW was 2 days before collecting for analysis. Water samples were collected from RGW, FGW (from sand and gravel filter) and TGW. Samples were collected in polyethylene bottles prewashed with acid and distilled water and then dried and, taken to the laboratory for analysis. The parameters analysed were BOD, COD, TSS, TN and FC. 


\section{Results and Discussion}

\section{Removal efficiencies for $F G W$ and $T G W$}

Pollutants removal efficiencies for BOD, COD, TSS, TN and FC were $80.20 \%, 78.35 \%, 56.07 \%, 45.93 \%$ and $74.71 \%$, respectively, for FGW and 90.92\%, 91.46\%, 93.46\%, 53.66\% and $82.10 \%$, respectively, for TGW (Table 1). These values are in conformity with Ridderstolpe (2004) [27], who reported 90 99\% removal efficiencies for both BOD and COD, and 30\% nitrogen removal for vertical subsurface flow. Previous report by Deguenon et al. (2013) [9] also showed that COD and BOD had removal efficiencies of $93 \%$ and $92 \%$, respectively, when common reed was used to treat a campus domestic sewage. Similar reports by Marzec et al. (2018) [22] showed that more than $95 \%$ of BOD and COD were removed in the tested hybrid CW system planted with common reed. This removal efficiency was credited to high oxygen transfer through the substrate media at which its vertical configuration promote better contact with microorganism and substrate aeration [18]. The likely reason for lower values in FGW as compared to TGW may be due to low levels of degradable organic matter entering the sedimentation tank, therefore, much of it might have been reduced in the process of filtration.

The reduction tool for nitrate included uptake by plants and micro-organisms, ammonification, nitrification, denitrification, ammonia volatilization and cation exchange for ammonium [32]. The outcomes showed that plants played a big role in the removal of nitrate from greywater to corroborate other studies. For instance, Kaseva (2004) [17] reported a removal efficiency of nitrogen of $40.3 \%$ in a CW phragmites planted cells while Sarafraz et al. (2009) [29] working with subsurface $\mathrm{CW}$ planted with phragmites in Teheran University (Iran), reported a removal efficiency of nitrogen as $79 \%$ in planted cells. The higher nitrogen removal efficiencies in each case was probably due to a longer retention time of 2 days [19]. Similar results were reported by Stefanakis and Tsihrintzis (2012) [30], in an evaluation of fully matured Vertical Flow Constructed Wetland system (VFCWs) for treating synthetic wastewater, where the wetland systems achieved higher nitrogen and organics removal as the HLR increased from $0.7 \mathrm{~m} /$ day to 2.1 $\mathrm{m} /$ day. The number of fecal coliforms (FC) in the present $\mathrm{RGW}(2570 \mathrm{CFU} / \mathrm{ml})$ was low as compared to many other studies elsewhere. For example, Garcia et al. (2004) [12] reported EC counts averaging $9.7 \times 10^{6} \mathrm{CFU} / 100 \mathrm{ml}$ for the influents, before entering a $\mathrm{CW}$ system. Similar to the present study, the RGW in their study was thereafter subjected to primary treatment to reduce the amount of solid waste and prevent pipe clogging in the wetland. The higher removal efficiency of fecal indicator bacteria in $\mathrm{CW}$ in this study $(74.71 \%$ for FGW and $82.10 \%$ for TGW) is in line with the reports of improved contaminants removal efficiency of CW when planted with wetland plants $[16,6]$. In many cases, removal efficiencies of feacal indicator bacteria (FC) have been reported to be nearly greater than $90 \%$ using reed beds plants in wetlands. Chong et al. (2013) [8] for example, reported FC removal efficiency of $88 \%$ to $99 \%$ in Kentucky (United States) when decorative flowering plants were used.

Table 1. Performance efficiencies of different greywater treatment materials.

\begin{tabular}{llllll}
\hline Parameter & $\begin{array}{l}\text { Raw } \\
\text { greywater }\end{array}$ & $\begin{array}{l}\text { Filtered greywater } \\
\text { (FGW) }\end{array}$ & $\begin{array}{l}\text { Removal Efficiency } \\
\text { (\%) FGW }\end{array}$ & $\begin{array}{l}\text { Treated greywater } \\
\text { (TGW) }\end{array}$ & $\begin{array}{l}\text { Removal Efficiency } \\
\text { (\%) TGW }\end{array}$ \\
\hline BOD (mg/l) & 286.40 & 56.70 & 80.20 & 26.00 & 90.92 \\
COD (mg/l) & 415.77 & 90.00 & 78.35 & 35.51 & 60 \\
TSS (mg/l) & 107.00 & 47.00 & 56.07 & 7.00 & 91.46 \\
TN (mg/l) & 24.60 & 13.30 & 45.93 & 11.40 & 93.46 \\
FC (cfu/ml) & 2570 & 650 & 74.71 & 460 & 53.66 \\
\hline
\end{tabular}

\section{Conclusion}

The research was conducted to evaluate the performance efficiency of common reed, sand and gravel for greywater treatment in a CW in Akure, Nigeria. The efficiencies of the different materials were tested based on their individual abilities to remove BOD, COD, TSS, TN and FC from the RGW. Consequently, it was found that the performance efficiency of common reed was better than those of sand and gravel for most of the parameters tested. However, given the relative performance of both sand and gravel as pretreated materials and their ability to achieve certain levels of filtration, we suggest that the high removal efficiency achieved by the common reed planted in the CW may have been made possible by the pretreatment achieved by the substrate materials (sand and gravel). Hence, it was concluded that the combination of the two substrates on one hand with the common reed in CWs is capable of ensuring greater removal and performance efficiency in greywater treatment. Given the suitability of both the FGW and TGW for irrigation water according to internationally acceptable standard, we recommend that the adoption of the combined system will help farmers in ensuring adequate treatment of greywater for application in both field crop irrigation and other outdoor needs.

\section{References}

[1] Ailstock, S. M. (2000). Adaptive strategies of Common Reed (Phragmites australis). In: The Role of Phragmites in the MidAtlantic Region, Princess Anne, MD, April 17, Environmental Center, Anne Arundel College, Arnold, MD.

[2] Albuquerque, A., Oliveira, J., Semitela, S., Amaral, L. (2009). Influence of Bed media Characteristics on Ammonia and Nitrate Removal in Shallow Horizontal Subsurface flow Constructed wetlands. Bioresour. Technol. 100: 6269-6277. 
[3] Allirand, J.-M. \& Gosse, G. (1995). An Aboveground Biomass Production Model for a Common reed (Phragmites communis Trin.) stand. Biomass and Bioenergy, 9 (6): 441448.

[4] Babatunde, A. O., Zhao, Y. Q., Zhao, X. H. (2010). Alum sludge-based Constructed Wetland system for Enhanced Removal of P and OM from Wastewater: Concept, Design and Performance Analysis. Bioresour. Technol. 101: 6576-6579.

[5] Boyjoo, Y., Pareek, V. K., \& Ang, M. (2013). A review of greywater characteristics and treatment processes. Water Science and Technology, 67 (7), 1403-1424.

[6] Boutilier, L., Jamieson, R., Gordon, R., Lake, C. and Hart, W. (2010). Performance of Surface Flow Domestic Wastewater Treatment Wetlands. Wetlands 30: 795-804.

[7] Brix, H. (1997). Do macrophytes play a role in constructed treatment wetlands? Water Sci. Choate, J. K., Edwards, F. R., Hirst, G. D. and O'shea, J. E. (1993). Effects of Sympathetic nerve stimulation on the Sino-atrial node of the Guinea-pig. The Journal of physiology, 471 (1), 707-727.

[8] Chong, H. L., Chia, P. S., Ahmad, M. N. (2013). The Adsorption of Heavy metal by Bornean Oil palm Shell and its Potential application as Constructed Wetland media. Bioresour. Technol. 130: 181-186.

[9] Deguenon, H. E. J., M. P. Hounkpe, J. A. Aina and D. C. K. Sohounhlore (2013). Purification Performances of Common Reed beds Based on the Residence time: Case study of Benin. Journal of Applied Biosciences 71: 5682-5691.

[10] Eriksson, E.; Auffarth, K.; Henze, M.; Ledin, A. Characteristics of grey wastewater. Urban Water 2002, 4 (1), 85-104.

[11] Friedler, E. Quality of individual domestic greywater streams and its implication for on-site treatment and reuse possibilities. Environ. Technol. 2004, 25 (9), 997-1008.

[12] García, J., Aguirre, P., Mujeriego, R., Huang, Y., Ortiz, L., Bayona, J. M. (2004). Initial Contaminant Removal Performance Factors in Horizontal flow Reed beds used for Treating Urban Wastewater. Water Res. 38: 16691678.

[13] Ghaitidak, D. M. and Yadav, K. D. (2013). Characteristics and treatment of greywater - a review. Environmental Science and Pollution Research, 20 (5), 2795-2809.

[14] Gross A (2008) Reliability of small scale greywater treatment systems and the impact of its effluent on soil properties. Int $\mathbf{J}$ Environ Stud 65 (1): 41-50.

[15] Haslam, S. M. (2010). A Book of Reed: (Phragmites australis (Cav.) Trin. ex Steudel, Formerly Kadlec, R. H. and Wallace, S. (2008). Treatment wetlands. CRC press.

[16] Karathanasis, A, Potter, C. and Coyne, M. (2003). Vegetation Effects on Fecal bacteria, BOD, and Suspended Solid Removal in Constructed Wetlands treating Domestic Wastewater. Ecol Eng 20: 157-169.

[17] Kaseva, M. (2004). Performance of Subsurface flow Constructed Wetland in polishing Pre-treated water: A tropical case study. J. Water Research. 38: 681-687.

[18] Kurniadie, D., Wijaya, D., Widayat, D., Umiyati, U. and Iskandar. (2018). Constructed Wetland to Treat Tapioca
Starch Wastewater in Indonesia. Asian Journal of Water, Environment and Pollution 15 (3): 10-113.

[19] Lee, C., T. D. Fletcher and G. Sun (2009). Nitrogen Removal in Constructed Wetland systems. Engineering in Life Sciences. 9 (1): 11-22.

[20] Li, C. J., Wan, M. H., Dong, Y., Men, Z. Y., Lin, Y., Wu de, Y. and Kong, H. N. (2011). Treating Surface water with Low nutrients Concentration by Mixed Substrates Constructed Wetlands. J. Environ. Sci. Health A 46: 771-776.

[21] Manh, N. C., Minh, P. V., Hung, N. T. Q., Son, P. T. and Ky, N. M. (2019). A study to assess the effectiveness of constructed wetland technology for polluted surface water treatment. VNU Journal of Science: Earth and Environmental Sciences 35 (2): 11-22.

[22] Marzec, M., K. Jozwiakowski, A. Debska, G. Gizinska-Goma, A. Pytka-Woszczylo, A. Kowalazyk-Jusko and A. Listosz (2018). The Efficiency and Reliability of Pollutant Removal in a Hybrid Constructed Wetland with Common reed, Manna grass and Virginia mallow. Water Journal 10: 1-18.

[23] Mlih, R., Bydalek, F., Klumpp, E., Yaghi, N., Bol, R. and Wenk, J. (2020). Light-expanded clay aggregate (LECA) as a substrate in constructed wetlands - A review. Ecological Engineering 148, 105783.

[24] Oteng-Peprah, M., Acheampong, M. A., \& DeVries, N. K. (2018). Greywater characteristics, treatment systems, reuse strategies and user perception - a review. Water, Air, \& Soil Pollution, 229 (8), 1-16.

[25] Pinto, U., Maheshwari, B. L. and Grewal, H. S. (2010). Effects of greywater irrigation on plant growth, water use and soil properties. Resources, Conservation and Recycling, 54 (7), 429-435.

[26] Prochaska, C. A. and Zouboulis, A. I. (2006). Removal of Phosphates by Pilot Vertical-flow Constructed Wetlands using a Mixture of Sand and Dolomite as Substrate. Ecol. Eng. 26: 293-303.

[27] Ridderstolpe, P. (2004). Introduction to Greywater Management. Stochholm Environment Institute, Sweden, Report 2004-4.

[28] Saeed, T., Sun, G. (2012). A Review on Nitrogen and Organics Removal Mechanisms in Subsurface Flow Constructed Wetlands: Dependency on Environmental parameters, operating conditions and supporting media. J. Environ. Manage. 112: 429-448.

[29] Sarafraz, S., Mohammad, T. A., Norr, M. J. and Laight, A. (2009). Wastewater Treatment using Horizontal Subsurface Flow Constructed Wetland. American Journal of Environmental Sciences, 5 (1): 99-105.

[30] Stefanakis, A. I. and V. A. Tsihrintzis (2012). Effect of Loading, Resting period, Temperature, Porous media, Vegetation and Aeration on Perfomance of Vertical flow Constructed Wetlands. Chem. Eng. J. 181-182: 416-430.

[31] Vymazal, J. (2010). Constructed wetlands for wastewater treatment. Water, 2 (3), 530-549.

[32] Vymazal, J. (2016). Concentration is not enough to Evaluate Accumulation of Heavy metals and Nutrients in Plants. Sci Total Environ 544: 495-498. 
[33] Wang, R., Korboulewsky, N., Prudent, P., Domeizel, M., Rolando, C. and Bonin, G. (2010).

[34] Feasibility of Using an Organic Substrate in a Wetland System Treating Sewage Sludge: Impact of Plant Species. Bioresour. Technol. 101: 51-57.

[35] World Health Organization (2006) WHO Guidelines for the safe use ofwa stewater, excreta and greywater. Volume 4, excreta and greywater use in agriculture. $\mathrm{http}: / / w w w . w h o . i n t / w a t e r$ sanitation health/wastewater/gsuw eg4/en/index.html. Accessed 28 September 2012.

[36] Yan, Y., Xu, J. (2014). Improving Winter Performance of Constructed Wetlands for Wastewater Treatment in Northern China: A review. Wetlands 34: 243-253. 